\title{
Assessment of Background Radiation Levels and Associated Doses in Soils of the Most Popular Tourist Place Muree, Pakistan
}

\author{
Khizar Hayat Satti ${ }^{1, *}$, Tania Jabbar ${ }^{2}$, M. Dilband ${ }^{1}$, Khalid Khan ${ }^{1}$, Abdul Rashid ${ }^{1}$, Abdul Jabbar ${ }^{1}$ \\ ${ }^{1}$ Health Physics Division, Pakistan Institute of Nuclear Science \& Technology (PINSTECH), Nilore, Islamabad, Pakistan \\ ${ }^{2}$ Punjab Institute of Nuclear Medicine (PINUM), Faisalabad, Pakistan
}

Copyright $\mathrm{C} 2017$ by authors, all rights reserved. Authors agree that this article remains permanently open access under the terms of the Creative Commons Attribution License 4.0 International License

\begin{abstract}
The activity concentration of natural and anthropogenic radionuclides and associated doses were determined in soil samples collected from Muree and its surroundings to provide baseline radioactivity data. High purity Germanium (HPGe) based spectrometry system was used for determination of activity concentration. The activity concentration of ${ }^{226} \mathrm{Ra},{ }^{232} \mathrm{Th},{ }^{40} \mathrm{~K}$ and ${ }^{137} \mathrm{Cs}$ varied between $\quad 20.0-29.5, \quad 43.4-62.4, \quad 163.0-493.6$ and $1.3-54.1 \mathrm{Bqkg}^{-1}$ respectively. Radium equivalent activity was measured in range 107-148 with average $128.0 \mathrm{Bqkg}^{-1}$.The average annual effective absorbed dose was found to be $72.9 \pm 1.0 \mu \mathrm{Svy}^{-1}$ which was comparable to world's average. The radium equivalent activity $\mathrm{Ra}_{\mathrm{eq}}$, indoor and outdoor hazard indices were lower than the safe limit of Organization for Economic Cooperation and Development (OECD) report for general public.
\end{abstract}

Keywords Soil, Radium Equivalent Activity, Indoor Radiation Hazard Index, Annual Effective Dose

\section{Introduction}

Natural radionuclides are the main contributors for doses to public [1]. It is therefore necessary to evaluate the risks arising from radiations [2]. Naturally occurring radionuclides (NORM) are the members of Uranium and Thorium decay chains and ${ }^{40} \mathrm{~K}$. Soil is the major source of natural radioactivity and concentrations of NORM radionuclides depends on the nature of the parent rock during soil formation [3]. Granitic rocks contain higher amounts of Thorium and Uranium as compared to other igneous rocks such as basaltic andesites [4]. Radon is the member of ${ }^{238} \mathrm{U}$ decay chain and contributes to half of the radiation doses received by general population [5]. Indoor radon concentration depends on the underlying rocks, soil and material used in construction. The global average dose per caput from radon inhalation, terrestrial and cosmic radiation is $2.42 \mathrm{mSv}$ per annum. Besides natural radionuclides, anthropogenic radionuclides are also present in the environment in varying amounts. Anthropogenic radionuclides originated from nuclear releases and nuclear weapon tests performed in early 1960's and dispersed through atmosphere. ${ }^{137} \mathrm{Cs}$ a fission product with high yield of $85 \%$ and half-life of 30 years is a prominent indicator of nuclear releases [2]. The levels of natural radioactivity in soil have been reported by many researchers in mid and southern Rechna interfluvial region [6, 7], Lahore [8], district Swat [9], Hunza [10], Mirpur [11], Bahawalpur division [12] of Pakistan and other parts of the World [13-17].

The objective of this study is to determine the back ground radiation levels in the most visited tourist destination of Pakistan Muree and its adjoining areas. This is the first systematic study to evaluate background radiation levels of area under study. The data obtained will be useful for the awareness of natural radioactivity and its associated health risks among inhabitants and tourists. Also, data obtained in this study will serve as base line to monitor any changes in back ground radiation levels due to geochemical processes or nuclear releases.

\section{Materials and Methods}

\subsection{Geology of Study Area}

The sampling was carried out in Muree known as 'Queen of hills' and its surroundings. The study area issituatedbetween $33^{0} 35^{\prime}-33^{0} 54^{\prime}$ latitude and $73^{0} 26^{\prime}-73^{0} 27$ longitude and is the most popular tourist destination in Pakistan [18]. The rocks of the study area include limestone, shale, sandstone, and brick-red clay, silty clay stone and purple to dark brown sandstone [19] .The 
elevation of the study area ranges from 2000 to 7200 feet above sea level. Its moderate climate, highlands and proximity to capital Islamabad catch the attention of tourist.

\subsection{Sample Collection, Pretreatment and Analysis}

Soil samples from different towns of Muree and its adjacent areas were collected using systematic gridding scheme according to IAEA guide lines [20]. The sampling points in the study area were identified using portable global positioning system (GPS) and are presented in figure1. The soil samples were oven dried ground to powder, passed through $2 \mathrm{~mm}$ mesh sieve and packed. Samples were stored for more than 28 days for the establishment of secular equilibrium of ${ }^{238} \mathrm{U}$ with its progeny. The radiometric analysis of samples was carried out using a high-resolution coaxial high purity Germanium detector (HPGe) Model GC2519 having relative efficiency $25 \%$. The detector had graded shielding $(15 \mathrm{~cm}$ thick lead having inner lining of $3 \mathrm{~mm}$ thick copper and $4 \mathrm{~mm}$ thick tin) to reduce the background by increasing backscattering [21]. Genie 2000 software was used for acquisition and analysis of spectrum. The quality of results was confirmed by using soil standard reference materials IAEA-375, IAEA-327 and RGK-1 obtained from International Atomic Energy Agency (IAEA). The activity concentration of the ${ }^{226} \mathrm{Ra}$ and ${ }^{232} \mathrm{Th}$ were estimated using the photo-peaks of their daughters $\left({ }^{214} \mathrm{~Pb}, 351 \mathrm{keV}\right.$ and $\left.{ }^{214} \mathrm{Bi} 609 \mathrm{keV}, 1120 \mathrm{keV}\right)$ and $\left.{ }^{228} \mathrm{Ac}, 911 \mathrm{keV}\right)$. Photo-peak at $662 \mathrm{keV}$ was used for ${ }^{137} \mathrm{Cs}$ and $1460.8 \mathrm{keV}$ for ${ }^{40} \mathrm{~K}$ activity determination. The minimum detectable activity values for ${ }^{226} \mathrm{Ra},{ }^{232} \mathrm{Th},{ }^{40} \mathrm{~K}$ and ${ }^{137} \mathrm{Cs}$ were $1.50,2.0,6.70$ and $1.10 \mathrm{Bqkg}^{-1}$ respectively.

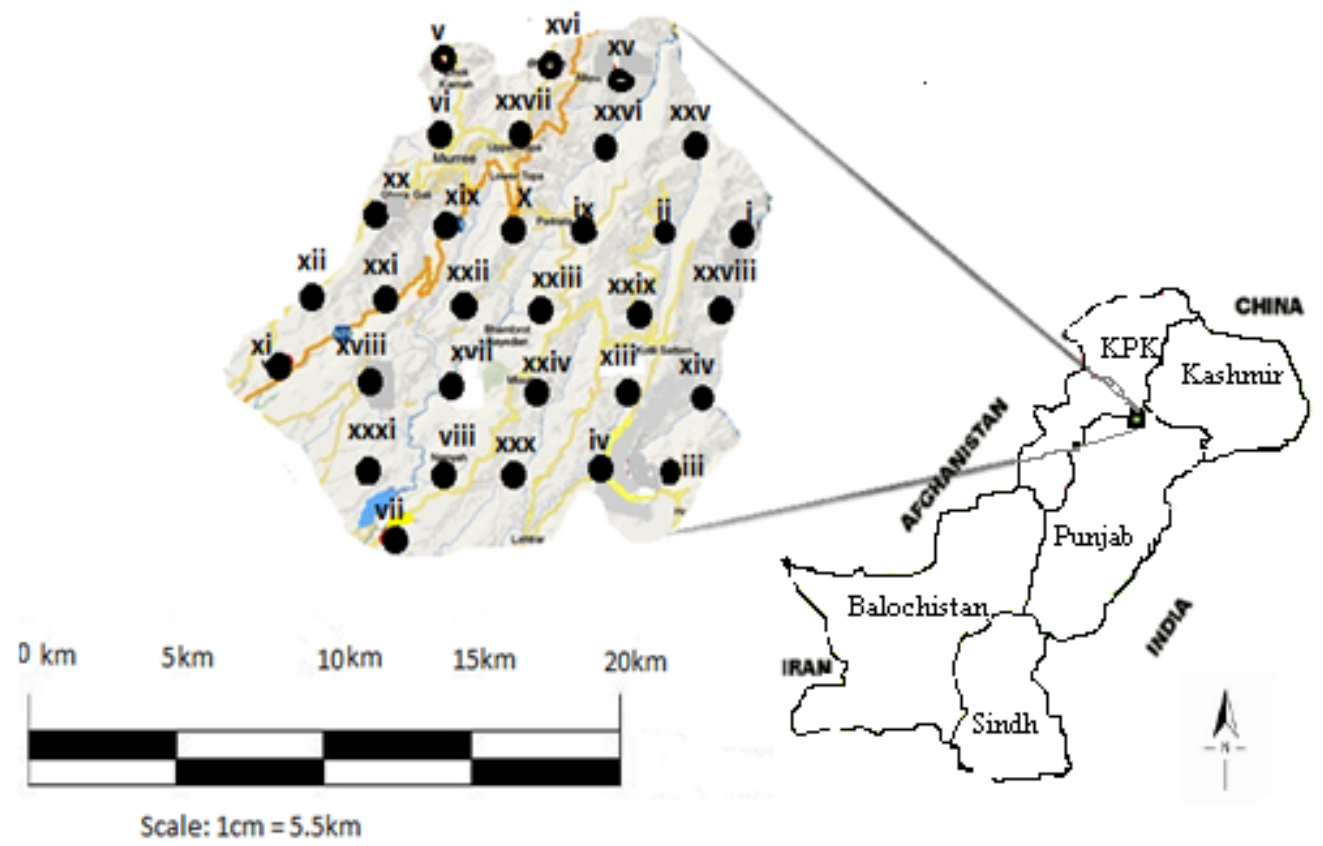

Figure1. Map of the study area

\section{Results and Discussions}

\subsection{Activity Concentrations}

The measured activity concentrations of ${ }^{226} \mathrm{Ra},{ }^{232} \mathrm{Th},{ }^{137} \mathrm{Cs}$ and ${ }^{40} \mathrm{~K}$ at various sampling locations on dry weight basis with uncertainties at 1sigma level are presented in Table1.The uncertainty measurements were performed using error propagation theory. 
Table 1. Activity Concentration of Natural Radionuclides and ${ }^{137} \mathrm{Cs}$

\begin{tabular}{|c|c|c|c|c|c|c|c|}
\hline \multirow{2}{*}{ Sr. No. } & \multirow{2}{*}{ Location } & \multirow{2}{*}{ Coordinates } & \multirow{2}{*}{ Altitude(ft) } & \multicolumn{4}{|c|}{ Activity Concentration $(\mathrm{Bq} / \mathrm{kg}) \pm 1 \sigma$} \\
\hline & & & & ${ }^{226} \mathrm{Ra}$ & ${ }^{232} \mathrm{Th}$ & ${ }^{40} \mathrm{~K}$ & ${ }^{137} \mathrm{Cs}$ \\
\hline I & Newala & $33.88^{\circ} \mathrm{N}, 73.58^{\circ} \mathrm{E}$ & 2287 & $24.3 \pm 1.5$ & $53.7 \pm 5.8$ & $377.4 \pm 23.3$ & $6.3 \pm 0.4$ \\
\hline II & Bahndi & $33.88^{\circ} \mathrm{N}, 73.54^{\circ} \mathrm{E}$ & 3438 & $26.2 \pm 1.3$ & $52.3 \pm 4.6$ & $421.1 \pm 20.5$ & $9.7 \pm 0.4$ \\
\hline III & Kamra & $33.73^{\circ} \mathrm{N}, 73.50^{\circ} \mathrm{E}$ & 4089 & $27.7 \pm 1.0$ & $57.9 \pm 2.6$ & $472.4 \pm 22.8$ & $10.3 \pm 0.3$ \\
\hline IV & Bhattian & $33.75^{\circ} \mathrm{N}, 73.49^{\circ} \mathrm{E}$ & 3782 & $25.9 \pm 1.4$ & $54.7 \pm 3.2$ & $435.0 \pm 23.1$ & $13.6 \pm 0.4$ \\
\hline $\mathrm{V}$ & Bariyan & $33.96^{\circ} \mathrm{N}, 73.39^{\circ} \mathrm{E}$ & 6980 & $28.9 \pm 1.1$ & $49.3 \pm 2.0$ & $424.8 \pm 23.2$ & $38.3 \pm 0.7$ \\
\hline VI & Dhar RF & $33.93^{\circ} \mathrm{N}, 73.39^{\circ} \mathrm{E}$ & 5890 & $27.8 \pm 1.0$ & $48.6 \pm 2.1$ & $3490 \pm 18.6$ & $23.6 \pm 0.3$ \\
\hline VII & Sambli colony & $33.72^{\circ} \mathrm{N}, 73.35^{\circ} \mathrm{E}$ & 2431 & $29.5 \pm 0.9$ & $51.9 \pm 3.1$ & $163.1 \pm 16.2$ & $1.3 \pm 0.1$ \\
\hline VIII & Nanjan & $33.74^{\circ} \mathrm{N}, 73.39^{\circ} \mathrm{E}$ & 3755 & $25.4 \pm 1.1$ & $55.3 \pm 4.1$ & $456.0 \pm 25.7$ & $4.7 \pm 0.1$ \\
\hline IX & Patriata & $33.85^{\circ} \mathrm{N}, 73.48^{\circ} \mathrm{E}$ & 7280 & $20.0 \pm 0.8$ & $43.4 \pm 3.1$ & $374.4 \pm 17.5$ & $3.6 \pm 0.2$ \\
\hline $\mathrm{X}$ & Messyari & $33.87^{\circ} \mathrm{N}, 73.46^{\circ} \mathrm{E}$ & 5843 & $22.7 \pm 0.9$ & $48.4 \pm 3.7$ & $409.0 \pm 20.8$ & $2.7 \pm 0.1$ \\
\hline $\mathrm{XI}$ & Tarmina & $33.80^{\circ} \mathrm{N}, 73.23^{\circ} \mathrm{E}$ & 2282 & $21.5 \pm 0.9$ & $45.1 \pm 3.4$ & $276.8 \pm 19.9$ & $2.3 \pm 0.1$ \\
\hline XII & Arokas & $33.84^{\circ} \mathrm{N}, 73.29^{\circ} \mathrm{E}$ & 2926 & $23.4 \pm 1.3$ & $60.4 \pm 4.8$ & $344.0 \pm 19.1$ & $16.6 \pm 0.3$ \\
\hline XIII & Kotli RF & $33.87^{\circ} \mathrm{N}, 73.52^{\circ} \mathrm{E}$ & 3960 & $20.6 . \pm 0.9$ & $45.5 \pm 3.7$ & $493.6 \pm 21.1$ & $54.1 \pm 0.8$ \\
\hline XIV & Barhad & $33.80^{\circ} \mathrm{N}, 73.55^{\circ} \mathrm{E}$ & 2574 & $28.5 \pm 1.5$ & $49.9 \pm 3.1$ & $417.0 \pm 22.3$ & $30.6 \pm 0.7$ \\
\hline $\mathrm{XV}$ & DewalRF & $33.98^{\circ} \mathrm{N}, 73.46^{\circ} \mathrm{E}$ & 5940 & $27.0 \pm 1.0$ & $62.4 \pm 4.1$ & $410.8 \pm 22.9$ & $26.4 \pm 0.5$ \\
\hline XVI & Talut & $34.03^{\circ} \mathrm{N}, 73.85^{\circ} \mathrm{E}$ & 3630 & $29.4 \pm 1.3$ & $47.7 \pm 2.8$ & $234.0 \pm 17.6$ & $10.6 \pm 0.4$ \\
\hline XVII & Suleha & $33.78^{\circ} \mathrm{N}, 73.40^{\circ} \mathrm{E}$ & 2546 & $25.4 \pm 1.0$ & $54.6 \pm 4.0$ & $288.1 \pm 19.0$ & $3.8 \pm 0.2$ \\
\hline XVIII & Balkh & $33.80^{\circ} \mathrm{N}, 73.33^{\circ} \mathrm{E}$ & 3585 & $22.2 \pm 0.8$ & $55.8 \pm 4.2$ & $376.0 \pm 20.3$ & $24.34 \pm 0.5$ \\
\hline XIX & Lawrence college & $33.88^{\circ} \mathrm{N}, 73.37^{\circ} \mathrm{E}$ & 5730 & $23.8 \pm 0.9$ & $50.6 \pm 3.9$ & $397.9 \pm 21.4$ & $20.8 \pm 0.5$ \\
\hline $\mathrm{XX}$ & Ghora Gali & $33.81^{\circ} \mathrm{N}, 73.33^{\circ} \mathrm{E}$ & 4505 & $24.1 \pm 0.9$ & $48.9 \pm 3.2$ & $387.0 \pm 21.2$ & $11.7 \pm 0.3$ \\
\hline XXI & Charra pani & $33.85^{\circ} \mathrm{N}, 73.32^{\circ} \mathrm{E}$ & 3610 & $27.6 \pm 1.2$ & $44.3 \pm 2.9$ & $287.0 \pm 18.7$ & $14.4 \pm 0.3$ \\
\hline XXII & Sambli Behramal & $33.83^{\circ} \mathrm{N}, 73.38^{\circ} \mathrm{E}$ & 3774 & $26.5 \pm 1.3$ & $57.2 \pm 4.1$ & $295.0 \pm 19.3$ & $8.3 \pm 0.2$ \\
\hline XXIII & Sanj & $33.84^{\circ} \mathrm{N}, 73.45^{\circ} \mathrm{E}$ & 4889 & $21.3 \pm 0.9$ & $48.5 \pm 3.1$ & $411.0 \pm 22.1$ & $15.9 \pm 0.4$ \\
\hline XXIV & Durbhandi & $33.79^{\circ} \mathrm{N}, 73.45^{\circ} \mathrm{E}$ & 4935 & $23.9 \pm 1.2$ & $44.6 \pm 2.7$ & $348.0 \pm 19.7$ & $3.9 \pm 0.2$ \\
\hline XXV & Chapprian & $33.93^{\circ} \mathrm{N}, 73.55^{\circ} \mathrm{E}$ & 2206 & $29.1 \pm 1.2$ & $50.7 \pm 3.3$ & $435.0 \pm 23.7$ & $12.8 \pm 0.2$ \\
\hline XXVI & Gohi Rf & $33.93^{\circ} \mathrm{N}, 73.50^{\circ} \mathrm{E}$ & 2896 & $20.5 \pm 0.8$ & $47.8 \pm 2.8$ & $408.0 \pm 22.6$ & $17.6 \pm 0.3$ \\
\hline XXVII & Kashmiri Bazar & $33.94^{\circ} \mathrm{N}, 73.45^{\circ} \mathrm{E}$ & 6386 & $23.2 \pm 0.9$ & $60.5 \pm 4.0$ & $312.0 \pm 16.6$ & $4.8 \pm 0.2$ \\
\hline XXVIII & Kuthian & $33.84^{\circ} \mathrm{N}, 73.54^{\circ} \mathrm{E}$ & 3979 & $25.1 \pm 1.3$ & $56.4 \pm 3.7$ & $457.0 \pm 25.3$ & $4.2 \pm 0.3$ \\
\hline XXIX & Sarmandal & $33.84^{\circ} \mathrm{N}, 73.49^{\circ} \mathrm{E}$ & 6596 & $20.5 \pm 1.1$ & $43.9 \pm 2.7$ & $421.0 \pm 23.4$ & $9.3 \pm 0.4$ \\
\hline \multirow[t]{2}{*}{$\mathrm{XXX}$} & Behl & $33.75^{\circ} \mathrm{N}, 73.43^{\circ} \mathrm{E}$ & 3436 & $23.6 \pm 1.4$ & $45.7 \pm 3.4$ & $342.0 \pm 22.3$ & $2.8 \pm 0.1$ \\
\hline & Channeri & $33.74^{\circ} \mathrm{N}, 73.33^{\circ} \mathrm{E}$ & 2934 & $21.5 \pm 0.9$ & $53.8 \pm 3.6$ & $287.0 \pm 18.3$ & $13.7 \pm 0.5$ \\
\hline
\end{tabular}

The mean radioisotope mass activities of terrestrial

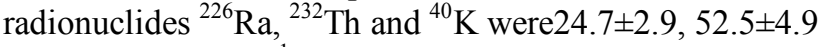
and $368 \pm 75.0 \mathrm{Bqkg}^{-1}$ with ranges(20-29.5), (43.4-62.4) and (163-493) $\mathrm{Bqkg}^{-1}$ respectively. The average value of ${ }^{137} \mathrm{Cs}$ concentration in study area was $13.6 \pm 11.8 \mathrm{Bqkg}^{-1}$. The quantitative analysis of data by Anderson Darling test showed that all the radionuclides ${ }^{226} \mathrm{Ra}$ ( $\mathrm{p}$-value $\left.=0.4\right),{ }^{232} \mathrm{Th}$ $(\mathrm{p}$-value $=0.8), \quad$ and ${ }^{40} \mathrm{~K} \quad(\mathrm{p}=0.1) \quad$ except $\quad$ Cs- 137 ( $\mathrm{p}$-value $<0.05$ ) were normally distributed about their mean with $95 \%$ confidence level. The activity concentrations of primordial radionuclides were observed to follow order as: ${ }^{226} \mathrm{Ra}<{ }^{232} \mathrm{Th}<{ }^{40} \mathrm{~K}$. The average values of activity concentration of natural radionuclides suggested that soil of Muree might have originated from sedimentary shale $[22]{ }^{232} \mathrm{Th} /{ }^{226} \mathrm{Ra}$ activity concentration ratio (i.e., progeny pair ${ }^{228} \mathrm{Ac} /{ }^{214} \mathrm{~Pb}$ ) can be used to assess the maintenance of the proportionality within the ${ }^{232} \mathrm{Th}$ and ${ }^{226} \mathrm{Ra}$ decay series.
In this study, ${ }^{232} \mathrm{Th} /{ }^{226} \mathrm{Ra}$ was found to vary from 1.7 to 2.3 with mean value of $2.1{ }^{232} \mathrm{Th}$ can be easily mobilized in forms of various complex inorganic cations and organic compounds. Thus, similar soil processes as reported for ${ }^{238} \mathrm{U}$ have contributed to the differential mobility of ${ }^{232} \mathrm{Th}$ and ${ }^{226} \mathrm{Ra}[2]$.

\subsection{Correlation Study}

A moderate correlation was observed between ${ }^{226} \mathrm{Ra}$ and ${ }^{232} \mathrm{Th}$ with $\mathrm{R}^{2}=0.6$. However, if four outliers were removed, correlation turned out to be a strong with $\mathrm{R}^{2}=0.8$ as shown in Figure $2 \mathrm{a} \& \mathrm{~b}$. This means that excluding four outliers $85 \%$ of ${ }^{232}$ Th activity followed ${ }^{226} \mathrm{Ra}$ activity in the study area which indicated that the natural radionuclides $\left({ }^{226} \mathrm{Ra}\right.$ and ${ }^{232} \mathrm{Th}$ series nuclides) might have a common source, i.e. the mineral components of the soil. 

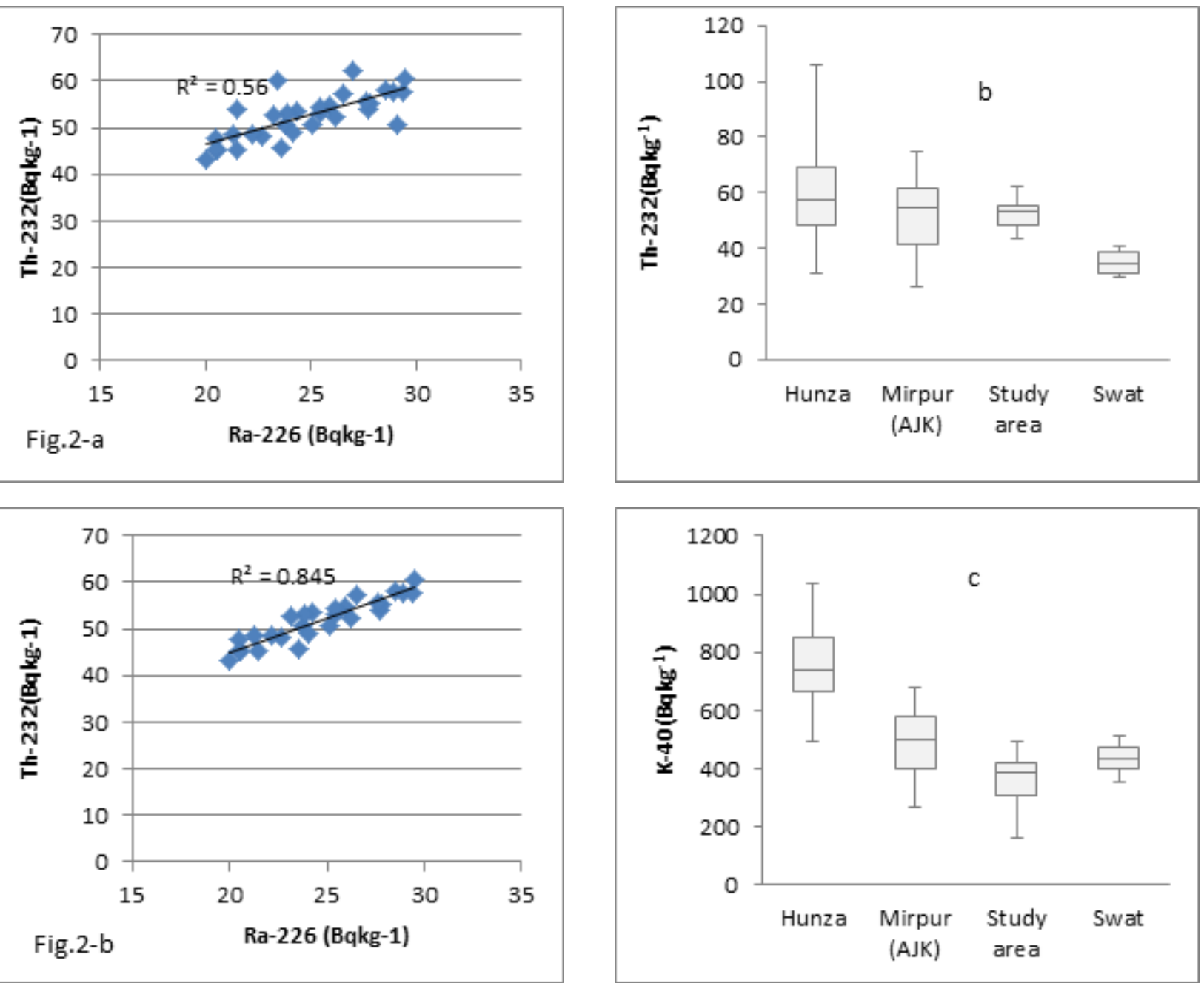

Figure 2. Correlation study

\subsection{Comparison}

A comparison of present data with other hilly areas of Pakistan i.e .Hunza [10], Mirpur(AJK) [11] and Swat[9] was also made through Box-Whisker plots as shown in Figure 3(a-d.).
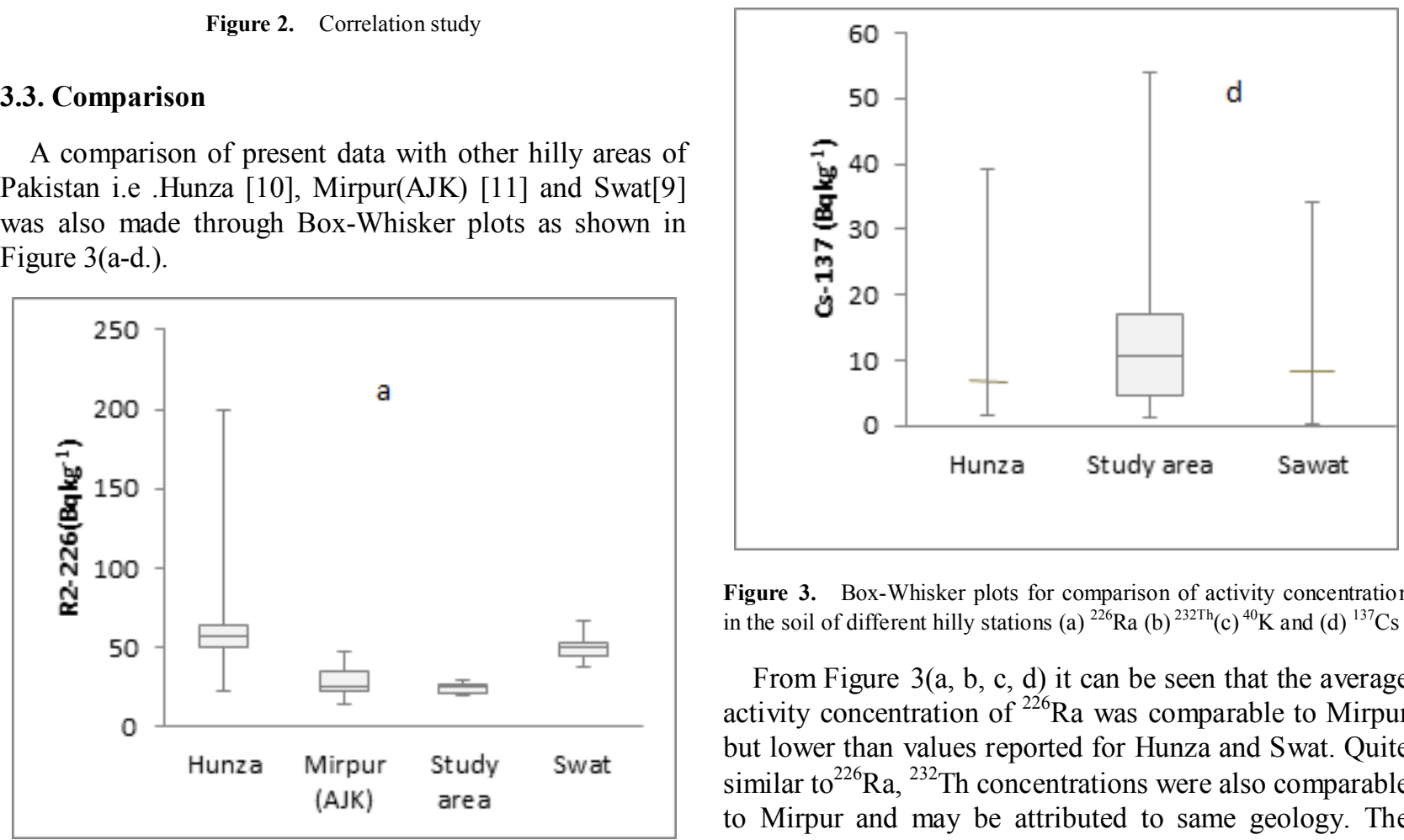

Figure 3. Box-Whisker plots for comparison of activity concentration in the soil of different hilly stations (a) ${ }^{226} \mathrm{Ra}(\mathrm{b}){ }^{232 \mathrm{Th}}(\mathrm{c}){ }^{40} \mathrm{~K}$ and (d) ${ }^{137} \mathrm{Cs}$

From Figure 3(a, b, c, d) it can be seen that the average activity concentration of ${ }^{226} \mathrm{Ra}$ was comparable to Mirpur but lower than values reported for Hunza and Swat. Quite similar to ${ }^{226} \mathrm{Ra},{ }^{232} \mathrm{Th}$ concentrations were also comparable to Mirpur and may be attributed to same geology. The 
average activity concentration of ${ }^{40} \mathrm{~K}$ was lowest in the study area. Although concentration was comparable to Swat but data had still overlapping with Mirpur. Of the radionuclides detected, ${ }^{137} \mathrm{Cs}$ had the most heterogeneous distribution in study area contrary to other compared areas where it was below MDA for most of sampling sites.

\subsection{Radium Equivalent Activity, Radiation Hazard Indices and Annual Effective Doses}

Most of the houses in the present study area are constructed using local rocks, walls and floors are labeled with mud and roofs are also covered by soil. The weighted sum of ${ }^{226} \mathrm{Ra}$, ${ }^{232} \mathrm{Th}$ and ${ }^{40} \mathrm{~K}$ activities, frequently used for the estimation of radiation hazards in building materials, is quantified by radium equivalent activity $\left(\mathrm{Ra}_{\mathrm{eq}}\right)[23]$. It is defined by following relation

$$
\mathrm{Ra}_{\mathrm{eq}}\left(\mathrm{Bqkg}^{-1}\right)=\mathrm{A}_{226 \mathrm{Ra}}+1.429 \mathrm{~A}_{232 \mathrm{Th}}+0.077 \mathrm{~A}_{40 \mathrm{~K}}
$$

Where, $\mathrm{A}_{226 \mathrm{Ra}}, \mathrm{A}_{232 \mathrm{Th}}$ and $\mathrm{A}_{40 \mathrm{~K}}$ are activity concentrations of ${ }^{26} \mathrm{Ra}^{232} \mathrm{Th}$ and ${ }^{40} \mathrm{~K}$ inBqkg ${ }^{-1}$ respectively. Any material is potentially radiotoxic if the value of $\mathrm{Ra}_{\mathrm{eq}}$ exceeds $370 \mathrm{Bqkg}^{-1}$ corresponds to annual effective dose of $1.05 \mathrm{mSv}$. The values of radium equivalent activity obtained in present study have been shown in Table 2 .

Table 2. Radiological Parameters

\begin{tabular}{|c|c|c|c|c|}
\hline Statistics & $\mathrm{Ra}_{\mathrm{eq}}\left(\mathrm{Bqkg}^{-1}\right)$ & $\mathrm{H}_{\mathrm{in}}$ & $\mathrm{H}_{\text {out }}$ & $\mathrm{AEDE}\left(\mu \mathrm{Svy}^{-1}\right)$ \\
\hline Minimum & 107.3 & 0.3 & 0.3 & 60.6 \\
\hline Maximum & 147.8 & 0.5 & 0.4 & 83.9 \\
\hline Mean & 128.3 & 0.4 & 0.3 & 72.9 \\
\hline Median & 128.5 & 0.4 & 0.3 & 72.3 \\
\hline $\begin{array}{c}\text { Safe limit/World's } \\
\text { Average }\end{array}$ & 370 & 1 & 1 & 70 \\
\hline
\end{tabular}

The $\mathrm{Ra}_{\mathrm{eq}}$ values vary from (107.2-148.4) with average value of $128.3 \pm 9.5 \mathrm{Bqkg}^{-1}$. The hazards associated with outdoor or indoor occupancy are represented by outdoor radiation hazard index $\left(\mathrm{H}_{\text {out }}\right)$ and indoor radiation hazard index $\left(\mathrm{H}_{\text {in }}\right)$ respectively [23]. These indices are calculated by using following formulae

$$
\begin{aligned}
& \mathrm{H}_{\text {out }}=\left(\mathrm{A}_{226 \mathrm{Ra}} / 370\right)+\left(\mathrm{A}_{232 \mathrm{Th}} / 259\right)+\left(\mathrm{A}_{40 \mathrm{~K}} / 4810\right) \\
& \mathrm{Hin}=\left(\mathrm{A}_{226 \mathrm{Ra}} / 185\right)+\left(\mathrm{A}_{232 \mathrm{Th}} / 259\right)+\left(\mathrm{A}_{40 \mathrm{~K}} / 4810\right)
\end{aligned}
$$

In the present study it was found that the values of $H_{\text {in }}$ and $\mathrm{H}_{\text {out }}$ at all towns were less than the recommended safe limit of unity. Air absorbed dose rate at one meter above ground due to terrestrial radiations is given by formula [24]

$$
\mathrm{D}\left(\mathrm{nGyh}^{-1}\right)=0.461 \mathrm{~A}_{226 \mathrm{Ra}}+0.623 \mathrm{~A}_{232 \mathrm{Th}}+0.0414 \mathrm{~A}_{40 \mathrm{~K}}
$$

The outdoor annual effective dose equivalent was estimated by using following relation [15]

$$
\mathrm{E}_{\text {out }}\left(\mu \mathrm{Svy}^{-1}\right)=0.7 \times \mathrm{D}\left(\mathrm{nGyhr}^{-1}\right) \times 0.2 \times 8760 \times 10^{-3}
$$

Where, $\mathrm{E}_{\text {out }}$ is out door effective dose equivalent, $0.7\left(\mathrm{SvGy}^{-1}\right)$ is Sievert to Grey conversion factor, 0.2 is outdoor occupancy factor. The average annual effective dose rate in study area was $72.9 \pm 1.0 \mu \mathrm{Svy}^{-1}$ was comparable to world's average value.

\section{Conclusions}

- The average values of ${ }^{226} \mathrm{Ra},{ }^{232} \mathrm{Th}$ and ${ }^{40} \mathrm{~K}$ lie within world wide range. The variation of activity concentration may be due to local variation in geology of sampling points. All the radionuclides were normally distrusted about their mean with $95 \%$ confidence interval except ${ }^{137} \mathrm{Cs}$. A moderate positive correlation was found to exist between ${ }^{226}$ Raand ${ }^{232}$ Th concentrations.

- Radiological parameters like $\mathrm{Ra}_{\mathrm{eq}}, \mathrm{H}_{\mathrm{in}}, \mathrm{H}_{\text {out }}$ and annual effective doses showed that the radiation hazards to inhabitants and tourists in the study area are insignificant.

\section{REFERENCES}

[1] UNSCEAR2000.Sources and effects of ionizing radiation, United Nations Scientific Committee on the Effects of Atomic Radiation, United Nations, New York. (2000).

[2] Izquierdo, N.A., Gaspar, L., Lopez-Vicente, M., Machín,J. Spatial distribution of natural and artificial radionuclides at the catchment scale (South Central Pyrenees) . Rad. Meas. 46(2), 261-269(2011).

[3] Vukasinovi, I., Dordevic,A., Rajkovic,M.B., Todorovic,D., Pavlovic,V.B. Distribution of natural radionuclides in anthrosol-type soil.Turk. J. Agric. For.34,539-54(2010).

[4] Sahoo,S.K.,Hosoda,M.,Kamagata,S.,Sorimachi,A.,Ishikawa ,T.,Tokonami,S.,Uchida,S.Thorium,uranium and rare earth elements concentration in weathered Japanese soils amples. Nucl. Sci. Technol. 1., 416-419(2011).

[5] United Nations Scientific Committee on the Effects of Atomic Radiation. "Sources and effects of ionizing radiation.UNSCEAR1994 report to the General Assembly, with scientific annexes."(1994).

[6] Jabbar, A., Arshed, W., Bhatti, A. S., Ahmad, S.S., Akhter, P., \&Anjum, M. I.. Measurement of soil radioactivity levels and radiation hazard assessment in southern Rechna interfluvial region, Pakistan. Environmental monitoring and assessment. 169(1-4), 429-438 (2010).

[7] Jabbar, A., Arshed, W., Bhatti, A.S., Ahmad, S.S., \& Dilband, M. Measurement of soil radioactivity levels and radiation hazard assessment in mid Rechna interfluvial region, Pakistan. Journal of radio analytical and nuclear chemistry.283(2),371-378.(2010)

[8] Akhtar, N., Tufail, M., Ashraf, M. and Iqbal, M.M. Measurement of environmental radioactivity for estimation of radiation exposure from saline soil of Lahore, Pakistan. Radiation Measurements, 39(1), pp.11-14(2005).

[9] Jabbar,T., Khan,K., Subhani,M., Akhter,P., Jabbar,A. 
Environmental gamma radiation measurement in District Swat, Pakistan.Rad.Prot.Dosim.132(1),88-93(2008).

[10] Ali,M., Iqbal,S., Wasim,M., Arif,M., Saif,F. Soil radioactivity levels and radiological risk assessment in the high lands of Hunza, Pakistan. Rad. Prot. Dosim. 153(3), 390-399(2013.)

[11] Rafique,M., Rehman,H., Malik,F., Rajput,M., Rahman,S., Rathore,M. Assessment of radiological hazards due to soil and building materials used in Mirpur Azad Kashmir; Pakistan Iran.J. Radiat. Res.9(2),77-87(2011).

[12] Ahad,A., UrRehman,S., urRehman,S. and Faheem,M. Measurement of radioactivity in the soil of Bahawalpur division, Pakistan. Radiation protection dosimetry, 112(3), pp.443-447(2004).

[13] Sahin,L., Hafizoğlu,N., Çetinkaya,H., Manisa,K., Bozkurt,E. and Biçer,A. Assessment of radiological hazard parameters due to natural radioactivity in soils from granite-rich regions in Kütahya Province, Turkey. Isotopes in environmental and health studies,53(2),pp.212-221(2017)

[14] Kumar,A., Kumar,S., Singh,J., Singh,P. and Bajwa,B.S. Assessment of natural radioactivity levels and associated doserates in soil samples from historical city Panipat, India. Journal of Radiation Research and AppliedSciences.10, 283-288(2017).

[15] Singh,J., Singh,H., Singh,S., Bajwa,B., Sonkawade,R. Comparative study of natural radioactivity levels in soil samples from the Upper Siwaliks and Punjab, India using gamma-ray spectrometry. J. Environ. Radioac. 100(1), 94-98(2009).
[16] Tabar,E., Yakut,H., Saç,M.M., Taşköprü,C., Içhedef,M. and Kuş,A. Natural radioactivity levels and related risk assessment in soil samples from Sakarya, Turkey. Journal of Radioanalytical and Nuclear Chemistry, 313(1), pp.249-259(2017).

[17] Omoniyi, I.M., Oludare, S.M., Oluwaseyi, M. Determination of radionuclides and elemental composition of clay soils by gamma -and X-ray spectrometry. Springer Plus 2(1), $1-11(2013)$.

[18] Taniya,S.H.A.H." Where Tourism Runs the Economy and Shapes the Culture. "in Tourism, Hospitality and Leisure:664.(2008)

[19] Kazmi, A.H., Jan,M.Q. Geology and tectonics of Pakistan, Graphic publishers Karachi(1997).

[20] International Atomic Energy Agency (IAEA). Measurement of radionuclides in food and environment. Technical Report Series No.295, Vienna(1989).

[21] Knoll,G.F. Radiation detection and measurement, John Wiley \& Sons(2010).

[22] Tyler, AN. Environmental influences on gamma ray spectrometry, Ph.D. Thesis, The Science Faculty, University of Glasgow (1994).

[23] Beretka,J., Mathew,P. Natural radioactivity of Australian building materials, industrial waste sand by-products. Health Phys. 48(1), 87-95(1985).

[24] Khan,K., Khalid,M.R., Jabbar,A., Akhter,P. Appraisal of radioactivity and associated radiation hazards in sand samples of four rivers of Punjab province, Pakistan. Isot. Environ. Healt. S. 48(2), 286-294(2012). 